\title{
What should we know about drug reaction with eosinophilia and systemic symptoms?
}

\author{
Sylvia A. Martinez-Cabriales ${ }^{1,2 *}$ \\ ${ }^{1}$ School of Medicine and Department of Dermatology, Autonomous University of Nuevo Leon, Nuevo Leon, Mexico; ${ }^{2}$ Department of Dermatology, \\ Faculty of Medicine, University of Toronto, Toronto, Canada
}

\section{Definition and pathogenesis}

Drug reaction with eosinophilia and systemic symptoms (DReSS) is a serious hypersensitivity drug reaction with multiorgan involvement. It occurs between 3 weeks and 3 months after the introduction of the culprit drug. However, a retrospective study reported a rapid onset of DReSS within 2 weeks of exposure ${ }^{1}$. The drugs most commonly related to this condition are carbamazepine, allopurinol, and sulfasalazine. Interestingly, some drugs have been related to specific organ damage, such as allopurinol to kidney damage; minocycline to lung injury; and minocycline and sulfonamides to heart disease.

Before the recognition of the anticonvulsant hypersensitivity syndrome ${ }^{2}$ in the 1980 s, skin reactions were named after the culprit drug. Since the first DReSS acronym and diagnostic criteria were proposed in 1996, the Japanese Research Committee on Severe Cutaneous Adverse Reaction and the RegiSCAR group published modified diagnostic criteria and a scoring system, respectively. More recently, it was proposed to use a lower case "e" (DReSS) to represent eosinophilia since this might be not be seen until a later course or might not be present at all ${ }^{3}$.

DReSS is a T-cell-mediated hypersensitivity reaction; nevertheless, its pathogenesis is not completely clear. It is known that human leukocyte antigen subtypes are linked to certain drugs and specific ethnicity and that viral reactivation is associated with a severe clinical presentation and disease flares. About the latter, it is demonstrated that the Treg and Th17 cells play a role in the herpesviruses reactivation and that differentiation of Treg into Th17 cells is associated with clinical resolution ${ }^{4}$.

\section{Diagnosis and management}

DReSS diagnosis is made based on the diagnostic criteria previously mentioned (Table 1). Prodromal symptoms are fever (present in $90 \%$ of cases), pruritus, lymphadenopathies, and dysphagia. During the acute phase, the most common symptom is a typically symmetrically distributed polymorphic skin eruption that tends to involve $>50 \%$ of the body surface area. Facial edema is frequently seen, and mucosal involvement may be present.

The organs most commonly affected are the liver, kidney, and hematologic system. Liver enzymes are increased in up to $70 \%$ of patients, and the development of severe hepatitis increases the risk of mortality ${ }^{5}$. Furthermore, eosinophilia is a frequently reported sign in this condition, although its appearance may be delayed.

Management focuses on the withdrawal of the suspicious culprit drug and supportive care. For severe cases, systemic corticosteroids are the mainstay treatment option. It is recommended to monitor the course of the disease with viral assessment in those cases.

\section{Correspondence:}

*Sylvia A. Martinez-Cabriales

E-mail: sylvia.mtzcabriales@gmail.com
Date of reception: 30-01-2020

Date of acceptance: $29-04-2020$ DOI: 10.24875/RMU.20000030
Available online: $18-06-2020$

Medicina Universitaria. 2020;22(2):86-87 www.medicinauniversitaria.org

作 2020 Universidad Autónoma de Nuevo León. Published by Permanyer. This is an open access article under the CC BY-NC-ND license (http://creativecommons.org/licenses/by-nc-nd/4.0/). 
Table 1. Diagnosis and management of DReSS

\begin{tabular}{|c|c|c|}
\hline \multicolumn{3}{|l|}{ Diagnosis criteria } \\
\hline Bocquet 1996 & $\begin{array}{l}\text { Japanese Research Committee on Severe } \\
\text { Cutaneous Adverse Reaction (J-SCAR) group }\end{array}$ & $\begin{array}{l}\text { RegiSCAR } 2007 \\
\text { Inclusion criteria for potential case of DReSS }\end{array}$ \\
\hline If three or more criteria: & $\begin{array}{l}\text { If all the seven criteria: typical DiHS. If the } \\
\text { first five criteria: atypical DIHS }\end{array}$ & $\begin{array}{l}\text { H Hospitalization }+ \text { Reaction suspected to be } \\
\text { drug related }+\geq 3 \text { of: }\end{array}$ \\
\hline 1. Cutaneous drug eruption & $\begin{array}{l}\text { 1. Maculopapular rash developing }>3 \text { weeks after } \\
\text { starting therapy with a limited number of drugs }\end{array}$ & 1. Acute skin rash \\
\hline $\begin{array}{l}\text { 2. Hematologic abnormalities } \\
\text { eosinophilia } \geq 1.5 \times 10^{9} / \mathrm{L} \text { or } \\
\text { presence of atypical lymphocytes }\end{array}$ & $\begin{array}{l}\text { 2. Prolonged clinical symptoms } 2 \text { weeks after } \\
\text { discontinuation of the causative drug }\end{array}$ & 2. Fever $>38^{\circ} \mathrm{C}$ \\
\hline \multirow{5}{*}{$\begin{array}{l}\text { 3. Systemic involvement } \\
\text { adenopathies } \geq 2 \mathrm{~cm} \text { in diameter } \\
\text { or hepatitis (liver transaminases } \\
\geq 2 \times \text { normal) or interstitial } \\
\text { nephritis or interstitial pneumonitis } \\
\text { or carditis }\end{array}$} & 3. Fever $>38^{\circ} \mathrm{C}$ & 3. Enlarged lymph nodes $\geq 2$ sites \\
\hline & $\begin{array}{l}\text { 4. Liver abnormalities (ALT > } 100 \mathrm{U} / \mathrm{L} \text { ) or other } \\
\text { organ involvement, such as renal } \\
\text { involvement }\end{array}$ & 4. Involvement of $\geq 1$ internal organ \\
\hline & $\begin{array}{l}\text { 5. Leukocyte abnormalities (at least one } \\
\text { present) a. Leukocytosis }\left(>11 \times 10^{9} / \mathrm{L} \text { ), }\right. \\
\text { b. Atypical lymphocytosis }(>5 \%) \text {, c. } \\
\text { Eosinophilia }\left(>1.5 \times 10^{9} / \mathrm{L}\right)\end{array}$ & \multirow{3}{*}{$\begin{array}{l}\text { Blood count abnormalities } \\
\text { 5. Lymphocytes above or below the } \\
\text { laboratory limits } \\
\text { 6. Eosinophils above the laboratory limits (in } \\
\text { percentage or absolute count) } \\
\text { 7. Platelets below the laboratory limits }\end{array}$} \\
\hline & 6. Lymphadenopathy & \\
\hline & 7. Human herpesvirus 6 reactivation & \\
\hline \multicolumn{3}{|l|}{ Management } \\
\hline All cases & \multicolumn{2}{|l|}{$\begin{array}{l}\text { Withdrawal of suspected culprit drug } \\
\text { Supportive care } \\
\text { Multidisciplinary evaluation } \\
\text { Monitoring of the course of the disease }\end{array}$} \\
\hline Mild cases & \multicolumn{2}{|c|}{ Symptomatic treatment, topical corticosteroid, $\mathrm{H} 1$ antihistamines } \\
\hline Moderate-to-severe cases & \multicolumn{2}{|c|}{$\begin{array}{l}\text { Systemic corticosteroids (equivalent } 1 \mathrm{mg} / \mathrm{kg} / \text { day of prednisone) with a slow taper over 3-12 } \\
\text { months } \\
\text { Alternative treatments: cyclosporine; IVIG; mycophenolate mofetil; systemic corticosteroids } \\
\text { with IVIG at a dose of } 2 \mathrm{~g} / \mathrm{kg} \text { over } 5 \text { days } \\
\text { Viral antibody titers and viral loads should be assessed at } 1-2 \text {-week intervals } \\
\text { Antiviral therapy is recommended if viral reactivation is confirmed }\end{array}$} \\
\hline
\end{tabular}

$\wedge$ : potential cases should be classified as definite, probable, possible or no case. based on the scoring system for classifying DReSS cases. Adapted from: Martinez-Cabriales SA, et al. ${ }^{3}$

DReSS is potentially fatal with a mortality rate of approximately $10 \%$; however, these data may not be accurate since many cases are unregistered. Moreover, its prognosis is unpredictable and long-term monitoring should be done to assess for autoimmune diseases or end-organ failure.

\section{Conflicts of interest}

The author declares that they have no conflicts of interest.

\section{References}

1. Soria A, Bernier C, Veyrac G, Barbaud A, Puymirat E, Milpied B. Drug reaction with eosinophilia and systemic symptoms may occur within 2 weeks of drug exposure: a retrospective study. J Am Acad Dermatol. 2019;82:606-11.

2. Shear NH, Spielberg SP. Anticonvulsant hypersensitivity syndrome. In vitro assessment of risk. J Clin Invest. 1988;82:1826-32.

3. Martinez-Cabriales SA, Rodriguez-Bolanos F, Shear NH. Drug reaction with eosinophilia and systemic symptoms (DReSS): how far have we come? Am J Clin Dermatol. 2019;20:217-36.

4. Shiohara T, Mizukawa Y. Drug-induced hypersensitivity syndrome (DiHS)/drug reaction with eosinophilia and systemic symptoms (DRESS): an update in 2019. Allergol Int. 2019;68:301-8.

5. Martinez-Cabriales SA, Shear NH, Gonzalez-Moreno El. Liver involvement in the drug reaction, eosinophilia, and systemic symptoms syndrome. World J Clin Cases. 2019;7:705-16. 